\title{
The Effect Acid Addition on Characteristic Effervescent Tablet of Tamarillo
}

\author{
Fidela Violalita ${ }^{\#}$ and Rini B* \\ ${ }^{\#}$ Department of Food Technology, Agricultural Polytechnic State of Payakumbuh, Tanjung Pati, 26271, Indonesia \\ E-mail:violalita@yahoo.com
}

* Department of Agricultural Product Technology, Faculty of Agricultural Technology, Andalas University, Padang, 25163, Indonesia

\begin{abstract}
The aim of study was to determine the percentage of acid and its influence on characteristic effervescent tablet of tamarillo. The percentages of acid addition that consist with citric acid and tartaric acid (1:1) were $15 \%, 20 \%, 25 \%, 30 \%$ and $35 \%$. Water content, $\mathbf{p H}$ solution, vitamin $\mathrm{C}$ content, soluble duration, friability of tablet and organoleptic test on colour, aroma and flavour of tamarillo effervescent tablet were determined after addition of acid. The results showed that the difference in percentage of acid addition significantly affected to the water content, $\mathrm{pH}$ solution, soluble duration and friability of tablets. Based on organoleptic test, the tablet consist of $25 \%$ addition of acid was the best percentage of acid addition. The quality parameters in this percentage were the water content $6.09 \%$, pH solution 4.80 , vitamin $\mathrm{C} 498.0800 \mathrm{mg} /$ tablet, soluble duration 3.96 minute, friability of tablet $\mathbf{0 . 1 1 \%} \%$, while the averages of organoleptic test for colour were 3.40 (ordinary), aroma 3.36 (ordinary), and flavour 3.76 (like).
\end{abstract}

Keywords - tamarillo, effervescent tablet, citric acid, tartaric acid

\section{INTRODUCTION}

The consumers tend to consume fast and easy prepared of healthy drinks, one of it is effervescent tablet. Effervescent is defined as dosage forms that produce gas bubbles as chemical reaction in solution (liquid). The gas produced is commonly $\mathrm{CO}_{2}$ (carbon dioxide) [1]. Effervescent tablet is made by granule compression containing effervescent salts or other materials that released gases when mixed with water[2].

The products in effervescent tablet widely circulated in the market. Those contain synthetic flavours and synthetic dyes. The natural materials can be used as flavouring and colouring to substitute of synthetic materials, and thus tamarillo can be used in the making of effervescent tablet.

Usually, fresh tamarillo is sold at the traditional market. Its production will be overflow at the harvesting time, if the handling is not good, its storage time will be short, low quality and low price. Processing fruits to be various products, will be able to increase its economic value and extend the storage time.

Tamarillo contains anthocyanin which is a group of reddish dye and soluble in the water. It can be used as natural dye. Tamarillo contents of many nutrient such as Vitamin A 540-5600 SI, Vitamin B6 0,01-0,05 mg/100g, Vitamin C 15-42 mg/100g, Vitamin E 2mg/100g and rich of anthocyanin, beta-carotene, fiber, iron and potassium but low in sodium [3]. Effervescent tablet is made by compressing the active materials such as acid and carbonic source. When effervescent tablet put into the water, it reacted between acid and carbonic source to form sodium salt from acid, and then produces carbon dioxide. The acid and alkali react very quickly. In addition, the tablet also gives a good taste because of the carbonic contained in tablet improving the taste [4].

Pulungan et al [1] made effervescent tablet from sinom turmeric by using citric acid and tartaric acid as the acid source. The amount of acid to be added is $42 \mathrm{~g}, 100 \mathrm{~g}$ for turmeric and $40 \mathrm{~g}$ for sinom used as raw materials. The ratio of citric acid and tartaric acid used is $1: 1$ [1].

Effervescent salts is used to process from citric acid and tartaric acid combination, because if only used a single acid the making of the tablet is difficultly. Tartaric acid using as single acid produces weak and clot granule, if used the citric acid only, the mixture will be sticking and hard to form the granule. So the use of tartaric acid in the making of effervescent tablet has function to strengthen the granule and to avoid the clot occurred [2].

Based on description above, the aim of study was to determine the percentage of acid and its influence on characteristic effervescent tablet of tamarillo. 


\section{MATERIALS AND METHODS}

\section{A. Materials and instruments}

Tamarillo used in this study was good in condition, perfect dark-red skin, and uniform size. While, the additional materials were sugar (sucrose), dextrin, tween 80, aspartame, sodium bicarbonate, citric acid, tartaric acid and ascorbic acid. Whereas, the chemical testing was $1 \%$ starch solution, $0,01 \mathrm{~N}$ iodine solution, buffer solution, aquades, phenolphetalin and another materials required.

The instruments used in this study were cabinet dryer, pot, blender, mixer, aluminium spoon, knife, coarse sieve, filter cloth, 100 mesh sieve, weigher, aluminium foil, pan oven, basin, plastic containers. While, for physical and chemical analysis were covering oven, $\mathrm{pH}$ meter, stopwatch, drop pipette, Erlenmeyer, measuring cup, burette, desiccator, aluminium cup and another tools required.

\section{B. Research Design}

This research was designed by Completely Random Design with 5 treatments and 3 repetitions. Significant difference was determine Duncan's Multiple Range Test at $5 \%$. This study was conducted based on 5 treatment acid addition which consists of citric acid and tartaric acid at ratio $1: 1:$

$$
\begin{aligned}
& A=15 \% \text { Acid Addition } \\
& B=20 \% \text { Acid Addition } \\
& C=25 \% \text { Acid Addition } \\
& D=30 \% \text { Acid Addition } \\
& E=35 \% \text { Acid Addition }
\end{aligned}
$$

\section{Research implementation}

1) Tamarillo Instant : $25 \mathrm{~g}$ of dextrin and $1 \mathrm{ml}$ of tween 80 was added to $500 \mathrm{ml}$ tamarillo juices and shaken for 15 minutes by using a mixer. Solution was placed into a dryer container $(30 \mathrm{~cm} \times, 30 \mathrm{~cm} \times 1 \mathrm{~cm})$ and covered by juice's plastic (thickness less than $0,5 \mathrm{~cm}$ ). The container was put into a cabinet dryer at temperature $60^{\circ} \mathrm{C}$ for $8 \mathrm{~h}$ until dry extract formed. Dry extract was added sucrose at ratio $1: 2$ and mashed using a blender and sieved at 100 mesh.

2) Tamarillo Effervescent Tablet: The instant powder was added with acids (tartaric acid and citric acid at ratio 1 : 1) according to treatments. Percentage acid used was calculated based on weight of instant powder. Next, instant powder was added with aspartame and sodium bicarbonate to produce effervescent powder. It was weighed $4 \mathrm{~g}$ and added $500 \mathrm{mg}$ of ascorbic acid and entered into tablet mould. Weight of one tablet was $4.5 \mathrm{~g}$ ( Table 1).

TABLE I

THE FORMULA OF TAMARILLO EFFERVESCENT TABLET

\begin{tabular}{|c|l|c|c|c|c|c|}
\hline \multirow{2}{*}{ No } & \multirow{2}{*}{ Materials } & \multicolumn{5}{|c|}{ Treatment } \\
\cline { 3 - 7 } & & A & B & C & D & E \\
\hline 1 & Tamarillo instant $(\mathrm{g})$ & 150 & 150 & 150 & 150 & 150 \\
\hline 2 & Citric acid $(\mathrm{g})$ & 11.25 & 15.00 & 18.75 & 22.50 & 26.25 \\
\hline 3 & Tartaric acid $(\mathrm{g})$ & 11.25 & 15.00 & 18.75 & 22.50 & 26.25 \\
\hline 4 & Natrium bicarbonate $(\mathrm{g})$ & 52.50 & 52.50 & 52.50 & 52.50 & 52.50 \\
\hline 5 & Aspartarme $(\mathrm{g})$ & 7.50 & 7.50 & 7.50 & 7.50 & 7.50 \\
\hline 6 & Vitamin C (mg)* & 500 & 500 & 500 & 500 & 500 \\
\hline
\end{tabular}

*) for one tablet $(4,5 \mathrm{~g})$
3) Packaging: Effervescent tablet of tamarillo was packaged in aluminium foil as the primer packaging and the plastic packaging as the secondary one, and then sealed by plastic sealer.

\section{Quality assessment}

Quality assessments of tablet were water content, $\mathrm{pH}$ Solution, Vitamin C content, soluble duration, friability of tablet and organoleptic test such as colour, aroma and flavour of tamarillo effervescent tablet solution.

\section{RESULT AND DISCUSSION}

\section{A. Water Content}

Table 2 shows the water content of tamarillo effervescent tablet after addition of acid. Water content obtained in this study ranged from $4,66 \%$ to 6.51 for $\mathrm{A}$ and $\mathrm{E}$ treatments, respectively. From the results, increasing the percentage of acid addition increased the water content of effervescent tablet. Significant higher of water content was shown on tablet with $35 \%$ of acid addition. However, significant difference was not found between tablet with $35 \%, 30 \%$ and $25 \%$ of acid addition. While, the lowest water content was shown on the tablet with $15 \%$ of acid addition. The increasing of water content with increasing of acid addition was caused the tablet absorbed water easily. In addition, the characteristic citric acid and tartaric acid are hygroscopic. Julianti et al reported that the water content of effervescent tablet consist of passion fruit and 'Lau Kawar' sunkis orange obtained $3.08 \%$ [5]. On other hand, the water content of effervescent tablet consist of wuluh starfruit obtained $1.38 \%$ [6].

TABLE II

THE AVERAGE WATER CONTENT OF TAMARILLO EFFERVESCENT TABLET

\begin{tabular}{|l|c|}
\hline \multicolumn{1}{|c|}{ Treatments } & Water content (\%) \\
\hline E. $35 \%$ acid addition & $6.51 \mathrm{a}$ \\
\hline D. $30 \%$ acid addition & $6.20 \mathrm{a}$ \\
\hline C. $25 \%$ acid addition & $6.09 \mathrm{a}$ \\
\hline B. $20 \%$ acid addition & $5.50 \mathrm{~b}$ \\
\hline A. $15 \%$ acid addition & $4.66 \quad \mathrm{c}$ \\
\hline CV $=0.89 \%$ & \\
\hline
\end{tabular}

The numbers on the same row followed by the same small letters are not significantly difference at the level $5 \%$ according to DNMRT.

\section{B. $p H$ Solution}

Table 3 shows the $\mathrm{pH}$ solution of tamarillo effervescent tablet after addition of acid. $\mathrm{pH}$ of effervescent tablet decreased with increasing of acid addition. There was significant difference in $\mathrm{pH}$ values among effervescent tablet of tamarillo. Significant lower in $\mathrm{pH}$ value was shown in effervescent tablet with $35 \%$ of acid addition where the value was 5.91. while, the $\mathrm{pH}$ of effervescent tablet added with $15 \%$ of acid addition was higher significantly compared with other treatment.

The increasing percentage of acid addition caused decreasing of $\mathrm{pH}$ solution of tamarillo effervescent tablet. Addition of citric acid and tartaric acid increased the acidity and decreased $\mathrm{pH}$ value. Reduction of $\mathrm{pH}$ value was caused by increasing the number of $\mathrm{H}+$ ion from the acid. Contrary, increasing produces of $\mathrm{H}+$ ion caused decreasing of the $\mathrm{pH}$ value. 
Julianti et al reported that the $\mathrm{pH}$ of effervescent tablet consists of passion fruit and 'Lau Kawar' sunkis orange obtained 4.84 [5]. On other hand, the water content of effervescent tablet consist of wuluh starfruit obtained 4.55 [6]. It indicates that our results $(\mathrm{pH})$ correspond to their results.

TABLE III

THE EVERAGE PH SOLUTION OF TAMARILLO EFFERVESCENT TABLET

\begin{tabular}{|l|c|}
\hline \multicolumn{1}{|c|}{ Treatment } & pH solution \\
\hline A. 15\% acid addition & $5.91 \mathrm{a}$ \\
\hline B. 20\% acid addition & $5.43 \mathrm{~b}$ \\
\hline C. $25 \%$ acid addition & $4.80 \mathrm{c}$ \\
\hline D. 30\% acid addition & $4.35 \quad \mathrm{~d}$ \\
\hline E. 35\% acid addition & $4.00 \quad \mathrm{e}$ \\
\hline CV $=1.86 \%$ &
\end{tabular}

The numbers on the same row followed by the same small letters are not significantly difference at the level $5 \%$ according to DNMRT.

\section{Vitamin $C$}

From statistical analysis shows that the addition of acids was not significantly affected of Vitamin $\mathrm{C}$ content from tamarillo effervescent tablet. The average Vitamin $\mathrm{C}$ of tamarillo effervescent tablet were shown in Table 4.

TABLE IV

THE EVERAGE VITAMIN C CONTENT OF TAMARILLO EFFERVESCENT TABLET

\begin{tabular}{|l|c|}
\hline \multicolumn{1}{|c|}{ Treatments } & Vitamin C (mg/tablet) \\
\hline A. $15 \%$ acid addition & 501.0133 \\
\hline B. $20 \%$ acid addition & 498.6667 \\
\hline C. $25 \%$ acid addition & 498.0800 \\
\hline E. $35 \%$ acid addition & 496.9067 \\
\hline D. $30 \%$ acid addition & 494.2667 \\
\hline CV $=3.08 \%$ & \\
\hline
\end{tabular}

The vitamin $\mathrm{C}$ content of tamarillo effervescent tablet ranged from 494,2667 mg/tablet (D treatment) to 501,0133 $\mathrm{mg} /$ tablet (A treatment). It was caused by addition of $500 \mathrm{mg}$ Vitamin C (Ascorbic acid) in the making of effervescent tablet. Vitamin C contained in fresh fruit was $22 \mathrm{mg} / 100 \mathrm{~g}$ material, while in dry extract was $56.254 \mathrm{mg} / 100 \mathrm{~g}$ material. This is the reason why added $500 \mathrm{mg}$ Vitamin C (Ascorbic acid) in the making of tamarillo effervescent tablet.

\section{Soluble duration}

The addition of acids affected on soluble duration of tamarillo effervescent tablet significantly. The average soluble duration of tamarillo effervescent tablet were shown in Table 5.

TABLE V

THE EVERAGE SOLUBLE DURATION OF TAMARILLO EFFERVESCENT TABLET

\begin{tabular}{|l|c|}
\hline \multicolumn{1}{|c|}{ Treatment } & Soluble duration \\
\hline A. $15 \%$ acid addition & $4.44 \mathrm{a}$ \\
\hline B. $20 \%$ acid addition & $4.37 \mathrm{a} \mathrm{b}$ \\
\hline C. $25 \%$ acid addition & $3.96 \mathrm{a} \mathrm{b}$ \\
\hline D. $30 \%$ acid addition & $3.67 \quad \mathrm{~b} \mathrm{c}$ \\
\hline E. $35 \%$ acid addition & $3.09 \quad \mathrm{c}$ \\
\hline CV $=9.34 \%$ & \\
\hline
\end{tabular}

The numbers on the same row followed by the same small letters are not significantly difference at the level $5 \%$ according to DNMRT.

Soluble duration was the time required by the tablet in one of serves size to be able perfectly soluble in the certain volume of water. The soluble duration ranged from 3.09 minutes ( $\mathrm{E}$ treatment) to 4.44 minutes (A treatment). The increasing of acid addition caused effervescent tablet soluble in water more quickly. It was caused by the reaction occurred at dissolution time, which is the reaction between the acid compound and carbonic compound produced the carbon dioxide. If the component to form the effervescent is lack, the soluble duration being longer. The reaction between acid and carbonic during effervescent tablet dissolved in the water is shown in Fig.1.

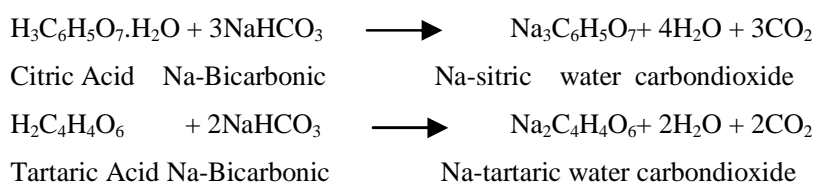

Fig. 1 The reaction between acid and carbonic

Julianti et al reported that soluble duration of effervescent tablet consists of passion fruit and 'Lau Kawar' sunkis orange obtained 1.04 minutes [5]. On other hand, the soluble duration of effervescent tablet consist of wuluh starfruit obtained 3.93 minutes [6].

\section{E. Friability of tablet}

The addition of acids affected on friability of tamarillo effervescent tablet significantly. The average friability of tamarillo effervescent was shown in Table 6.

TABLE VI

THE EVERAGE FRIABILITY OF TAMARILLO EFFERVESCENT TABLET

\begin{tabular}{|l|c|}
\hline \multicolumn{1}{|c|}{ Treatment } & Friability (\%) \\
\hline A. $15 \%$ acid addition & $1.46 \quad$ a \\
\hline B. $20 \%$ acid addition & $086 \quad$ b \\
\hline C. $25 \%$ acid addition & $0.11 \quad$ c \\
\hline D. $30 \%$ acid addition & $0.08 \quad$ c \\
\hline E. $35 \%$ acid addition & $0.02 \quad$ c \\
\hline CV $=35.52 \%$ & \\
\hline
\end{tabular}

The numbers on the same row followed by the same small letters are not significantly difference at the level $5 \%$ according to DNMRT.

The friability of tamarillo effervescent tablet ranged $0.02 \%$ (E treatment) to $1,4 \%$ (A treatment). The increasing of acid addition caused the lower of tablet friability. It indicates that tablet was not easily broken. The increasing of acid addition caused increasing of water content and tablet becomes more sticky and not broken easily.

Friability related with pressure. In moulding tablet, friability is given at pressure $80 \mathrm{~kg} / \mathrm{cm}^{2}$. When the pressure is given less than $80 \mathrm{~kg} / \mathrm{cm}^{2}$, resulting tablets are fragile and broken easily.

\section{F. Organoleptic Test}

1) Colour : E25 panellists tested the colour solution of tamarillo effervescent tablet. The average value on colour solution were shown in Table 7.

The soluble colour of tamarillo effervescent tablet ranged from 3.20 to 3.44 where for all treatments the panellists gave ordinary assessment. The highest values obtained at the D and $\mathrm{E}$ treatments. The colour produced from the effervescent tablet solution was muddy yellow (A treatment) till light yellow and clear (E treatment). 
TABLE VII

AVERAGE VALUE OF COLOUR TESTING

\begin{tabular}{|l|c|}
\hline \multicolumn{1}{|c|}{ Treatments } & Water content (\%) \\
\hline E. $35 \%$ acid addition & 3.44 \\
\hline D. $30 \%$ acid addition & 3.44 \\
\hline C. $25 \%$ acid addition & 3.40 \\
\hline B. $20 \%$ acid addition & 3.32 \\
\hline A. $15 \%$ acid addition & 3.20 \\
\hline CV $=29.23 \%$ & \\
\hline
\end{tabular}

Description: 1 = dislike very much, 2 = dislike, 3 = ordinary, $4=$ like, $5=$ like very much

The increasing of acid addition caused colour produced more clearly. This caused by tamarillo contains of metals that produced dark colour of solution. By addition of acids, this will bind up the metals and will produce clear and light yellow of colour.

2) Aroma : 25 panellists tested the aroma solution of tamarillo effervescent tablet. The average values to the aroma were shown in Table 8.

\section{TABLE VIII}

AVERAGE VALUE OF AROMA TESTING

\begin{tabular}{|l|c|}
\hline \multicolumn{1}{|c|}{ Treatments } & Water content $\mathbf{( \% )}$ \\
\hline C. $25 \%$ acid addition & 3.36 \\
\hline B. $20 \%$ acid addition & 3.08 \\
\hline D. $30 \%$ acid addition & 3.04 \\
\hline E. $35 \%$ acid addition & 3.00 \\
\hline A. $15 \%$ acid addition & 2.96 \\
\hline CV $=25.69 \%$ &
\end{tabular}

Description: $1=$ dislike very much, $2=$ dislike, $3=$ ordinary, $4=$ like, $5=$ like very much

The aroma of effervescent tablet solution ranged from 2.96 to 3.3 where for all treatments the panellists gave ordinary assessment. The increasing of acid addition reduced aroma of tamarillo. The highest assessment obtained on $\mathrm{C}$ treatment. On this treatment, the aroma of tablet solution had specific of tamarillo aroma. Acids addition did not give effect to the aroma produced, because the acids used did not have aroma.

3) Flavour: 25 panellists tested the flavour solution of tamarillo effervescent tablet. The average values of flavour were shown in Table 9.

TABLE IX.

AVERAGE VALUE OF FLAVOR TESTING

\begin{tabular}{|l|c|}
\hline \multicolumn{1}{|c|}{ Treatments } & Water content $\mathbf{( \% )}$ \\
\hline C. $25 \%$ acid addition & 3.76 \\
\hline D. $30 \%$ acid addition & 3.68 \\
\hline B. $20 \%$ acid addition & 3.56 \\
\hline E. $35 \%$ acid addition & 3.52 \\
\hline A. $15 \%$ acid addition & 3.12 \\
\hline CV $=24.26 \%$ & \\
\hline Description $: 1=$ dislike very much, $2=$ dislike, $3=$ ordinary, $4=$ like, $5=$
\end{tabular}

The taste of effervescent tablet solution ranged from 3.12 to 3.76 where for A treatment the panellists gave ordinary assessment and for B, C, D and E treatment the panellists gave like assessment. The increasing of acid addition caused flavour of tablet solution more acidic. The highest assessment obtained on $\mathrm{C}$ treatment. The solution in this treatment did not have strong taste. According to Pulungan et al [1], effervescent tablet also gives a good taste because of the carbonic improve the taste [1].

\section{CONCLUSIONS}

Based on the study, it can be concluded that the acid addition significantly affect to the water content, $\mathrm{pH}$, soluble time and the friability of the tamarillo effervescent tablet. Effervescent tablet by addition $25 \%$ of acid was the best percentage because it most like by the panellists. This percentage had $6.09 \%$ of water content, 4.80 of $\mathrm{pH}$ solution, $498.0800 \mathrm{mg} /$ tablet of Vitamin C, 3.96 minutes of soluble time, $0.11 \%$ of fragility and the averages of organoleptic test were 3.40 (ordinary), 3,36 (ordinary), and 3,76 (like) for colour, aroma and flavour, respectively.

\section{REFERENCES}

[1] Pulungan, M. Hindu., Suprayogi. Beni Yudha. Effervescent Tanaman Obat. Trubus Agrisarana. Surabaya. 2004.

[2] Ansel, H.C. Pengantar Bentuk Sediaan Farmasi, Edisi IV. UI Press. Jakarta. 1989.

[3] Kumalaningsih, Sri dan Suprayogi. Tamarillo (Terung Belanda). Trubus Agrisarana. Surabaya. 2006.

[4] Rohdiana, Dadan. 2003. Mengenali Teknologi Tablet Effervescent. [Online]. Available http://www.pikiranrakyat.com/cetak/0403/10/cakrawala/lainnya2.htm

[5] Julianti, Elisa., Setyohadi dan A. Halim Sulaiman. . Formulasi Tablet Effervescent dari Campuran Sari Markisa dan Jeruk Sunkis Lau Kawar. Rekayasa dan Teknologi Pengolahan. Yogyakarta. PATPI. 2006. pp 200-207.

[6] Luthfiya, Iffa Hidayati. Formulasi Tablet Effervescent Dari Ekstrak Daun Belimbing Wuluh (Averhoa bilimbi L.) Sebagai Anti Hipertensi. Skripsi Fakultas Pertanian.. Bogor Agricultural University. Bogor. 2007. 